\title{
Nature of the Skarn-Borosilicate Deposit Giants of the Sikhote-Alin and Pamir Mountains
}

\author{
Academician A. I. Khanchuk ${ }^{a, b}$, V. V. Ratkin ${ }^{a, *}$, and O. A. Eliseeva ${ }^{a, * *}$ \\ Received December 25, 2020; revised January 25, 2021; accepted January 28, 2021
}

\begin{abstract}
It is shown that the giant Sikhote-Alin and Pamir deposits of boron are associated with fragments of the boron-bearing evaporite strata of paleoceanic atolls in the subduction mélange. Ore formation relates both to in situ transformation of boron-bearing evaporite strata at the Ak-Arkhar deposit and to boron mobilization and redeposition some distance away from the evaporite source in course of intensive post-accretionary fluid-magmatic reworking of the subduction mélange at the Dalnegorskoe deposit.
\end{abstract}

Keywords: subduction mélange, atolls, evaporite, skarns, danburite, boron deposit, Dalnegorskoe, Ak-Arkhar DOI: $10.1134 / \mathrm{S} 1028334 \mathrm{X} 2105007 \mathrm{X}$

Among several hundreds of skarn-borosilicate deposits, only two objects have reserves comparable with the deposits of boron-bearing evaporites. These are the Dalnegorskoe deposit in the southeastern part of Sikhote-Alin $\left(44^{\circ} 34^{\prime} \mathrm{N}\right.$ and $135^{\circ} 37^{\prime} \mathrm{E}$; more than 35 million tons of $\mathrm{B}_{2} \mathrm{O}_{3}$ ) and the Ak-Arkhar deposit in the Pamirs $\left(37^{\circ} 58^{\prime} \mathrm{N}\right.$ and $73^{\circ} 42^{\prime} \mathrm{E} ; 7.2$ million tons of $\mathrm{B}_{2} \mathrm{O}_{3}$ ). Both deposits are confined to the subduction mélange of Mesozoic age and are manifested with phenomenal reserves as isolated point objects, without a plume of the same type of small deposits and ore occurrences in their environment. This feature and the specificity of the geological conditions of the localization made it possible earlier to assume [1] that the skarn borosilicate ores of the Dalnegorskoe deposit were formed due to boron from accumulations of evaporites, fragments of lagoon carbonate deposits of oceanic atolls in the subduction mélange. This model has found substantive confirmation in modern studies of the geology and minerals of these deposits.

The Dalnegorskoe deposit is located in the southeastern part of the Sikhote-Alin orogenic belt, formed as a collage of Jurassic and Early Cretaceous terranes [2]. The ore-bearing rocks at the deposit are represented by a subduction mélange stratum in the accretionary prism of the Taukha terrane. A characteristic

\footnotetext{
${ }^{a}$ Far East Geological Institute, Far East Branch, Russian Academy of Sciences, Vladivostok, 690022 Russia

${ }^{b}$ Institute of Ore Deposits, Petrography, Mineralogy, and Geochemistry, Russian Academy of Sciences, Moscow, 119017 Russia

*e-mail:ratkin@yandex.ru

**e-mail: okaras@yandex.ru
}

feature of the mélange is the abundance of large (up to several kilometers long) sheetlike inclusions of Triassic limestones enclosed in a sandy-shale Jurassic-Cretaceous prism matrix. It is established [3] that the limestones underlain in the primary bedding by oceanic basalts are fragments of guyots, the formation history of which includes the stages of a volcanic island, an atoll, and an underwater uplift (guyot, seamount). Subsequently, a conceptual model of carbonate sedimentation based on the data of detailed paleontological facies analysis [4] was developed. It corresponds to a system of the mid-oceanic atoll type, consisting of a well-developed lagoon with fringing bands of reefs and oolitic spits. The Triassic carbonate rocks that form inclusions in the mélange, with the facies dominance of marine lagoon formations, are dominated by micro- and macrofauna typical of the tropical zone of Pantalassa.

The deposit is manifested as a zone of calcareous skarns, replacing the bedlike body of Triassic limestones (Fig. 1). Skarns in the volume of the deposit appeared twice [5]. At an early stage, a column of grossular-wollastonite skarns was formed in the limestone body, almost completely replacing limestones in the range of modern depths from 0.5 to $1.2 \mathrm{~km}$. Above the column, in limestones, extended paleohydrothermal cavities were formed, successively filled with datolitebustamite (dalnegorskite)-hedenbergite mineral buds with ferrosilite and danburite [6]. In the Late Campanian time, 78.4 Ma [7], at the end of the early stage, a basalt melt was injected into the preserved space of the cavities. In the Paleocene, at a depth of about $1200 \mathrm{~m}$ from the modern surface, grossular-wollastonite skarns with danburite were bounded by the Dalnegorsk complex granitoids intrusion (Fig. 1), dated at $60.45 \pm 0.65 \mathrm{Ma}[8]$, which cut the zone. In associa- 
tion with the intrusions of the Dalnegorsk granitoids, the second stage of skarn activity and the formation of skarn and vein polymetallic ores of the Dalnegorsk region appeared. The previously formed danburite ore deposit, which appeared on the flank of the Partizanskoe $\mathrm{Pb}-\mathrm{Zn}$ deposit, was underwent a repeat skarn process into a commensurate zone of ilvaite-andradite-hedenbergite skarn. Danburite was transformed into a coarse-crystalline quartz-calcite aggregate. At the same time, the boron that was mobilized during the hydrothermal processing of early ores was fixed in the same zone in the form of datolite and axinite in association with late skarns [5,9]. The primary danburite ores avoided replacement and redeposition only in the northeastern part of the Dalnegorskoe deposit (Fig. 1). Thermobarogeochemical study showed that danburite was formed in the temperature range 350$200^{\circ} \mathrm{C}$ with the participation of solutions enriched with $\mathrm{CO}_{2}$ and saturated with sodium and magnesium chlorides, with an increase in their salinity from 2.9 to 16.34 wt $\%$ eq. $\mathrm{NaCl}$ under decreasing temperatures [5]. According to [10], mineral associations with danburite were formed with the participation of fluids with anomalous boron and lithium contents in the range of $6.20-53.80$ and $0.104 \mathrm{~g} / \mathrm{kg}$ of solution, respectively. This feature of fluids of the early stage was also manifested in the geochemical enrichment of grossular-wollastonite skarns with danburite in lithium and manganese, at average values of 49.8 and $5629.8 \mathrm{ppm}$, respectively. This indicates the presence of a specific source of solutions enriched in chlorides, magnesium, manganese, and lithium with abnormally high boron contents. At the same time, the specificity of danburite ores is also clearly manifested in the isotopic composition of boron. According to our data [11], danburite boron, at $\delta^{11} \mathrm{~B}=+17.7 \%$, corresponds to evaporites of marine origin. According to study of the oxygen isotopic composition [5], the formation of danburite occurred from the intensely diluted meteoric component of solutions of magmatic origin, with fluid $\delta^{18} \mathrm{O}$ values of about $-1.0 \%$.

The anomalous enrichment of the fluid that formed the danburite accumulations fully agrees with the data of experimental works [12], which shows that the crystallization of danburite occurs at a temperature of $300-400^{\circ} \mathrm{C}$ from a solution containing from 3.75 to $8.0 \mathrm{~mol}$ of $\mathrm{H}_{3} \mathrm{BO}_{3}$ per $1000 \mathrm{~g}$ of $\mathrm{H}_{2} \mathrm{O}$. This assumes the presence of a highly concentrated source of boron prior to skarn formation. The source of boron can be either centers of deeply differentiated granite magma with a typical manifestation of pegmatite formation [10] or accumulations of evaporites. However, the absence of granitoids with at least some noticeable pegmatite formation in the ore-bearing area, with a phenomenally large volume of danburite ores, excludes the former. This conclusion is confirmed directly by the heavier isotopic composition of the danburite boron and the characteristic enrichment of the fluid with lithium. The unusual increase in fluid salinity with the development of the crystallization of danburite probably also indicates the participation of evaporite salt-bearing deposits in the generation of ore-forming fluids.

The Ak-Arkhar field is located in the eastern part of the Bazar-Darinskii ridge (Pamir). The ore-bearing area is part of the Rushan-Pshart suture associated with Triassic subduction of the Paleo-Tethys oceanic basin plate beneath the South Pamir block [13]. The ore-bearing folded complex is composed of rocks of the Late Triassic accretionary prism, overlapped with unconformity by Middle Jurassic sediments. The prism is represented by Late Triassic flysch deposits and subduction mélange strata. The main types of inclusions in the mélange are parts of the oceanic guyot in the form of volcanic island basaltic base fragments and Late Permian and Triassic carbonate "caps" of the atoll and seamount (Fig. 2). Triassic inclusions are represented by isometric limestone bodies with interlayers of marls, dolomite limestones, and siliceous shales. Bedlike olistoliths are composed of a Late Permian stratum of a thin uniform interlayering (with a thickness of interlayers of $0.5-5.0 \mathrm{~cm}$ ) of oolitic, detrital, and conglomerate, sometimes dolomite, limestone, chert, and siliceous shale. Thin-platy siliceous rocks are usually gray, occasionally with a purple tint. Interlayers of shales and marls in the layered strata are often dolomite-bearing. The section also contains a tuff horizon of albitophyres, tuff schists, and tuff sandstones with lenses of pelitomorphic limestones and limestone tuff conglomerates. According to the siliceous-carbonate sedimentation type, the layered complex corresponds to the facies formed in the conditions of the shallow-water lagoon of the atoll with synchronous manifestation of volcanic exhalations.

Rocks of the accretionary prism participate in submeridional folding. At the same time, in the inclusions of siliceous-carbonate rocks, a small intense disharmonious folding with signs of plastic flow with characteristic corrugation of rocks and chaotic axial planes of fold orientations is manifested.

There is an intrusion of Early Cretaceous (110 \pm $3 \mathrm{Ma}$ [14]) granitoids exposed by wells in the center of the ore field. All rocks at the deposit, except for Paleogene diabase dykes, are hornfels, feldspathic and with skarns in the contact halo of this intrusion. As a result, the layered strata forming the Late Permian inclusions is manifested as an alternation of gray siliceous shales and fine-crystalline white-brown quartz-danburitegarnet skarnoids. With sharp clear contacts of orebearing skarnoids with cherts, the latter are practically not processed. Sometimes weakly altered shales and limestones also occur here. The composition of the skarnoid garnets corresponds to grossular-andradite. At the microstructural level, the quartz-danburite aggregate, crystallized immediately after the garnet, 

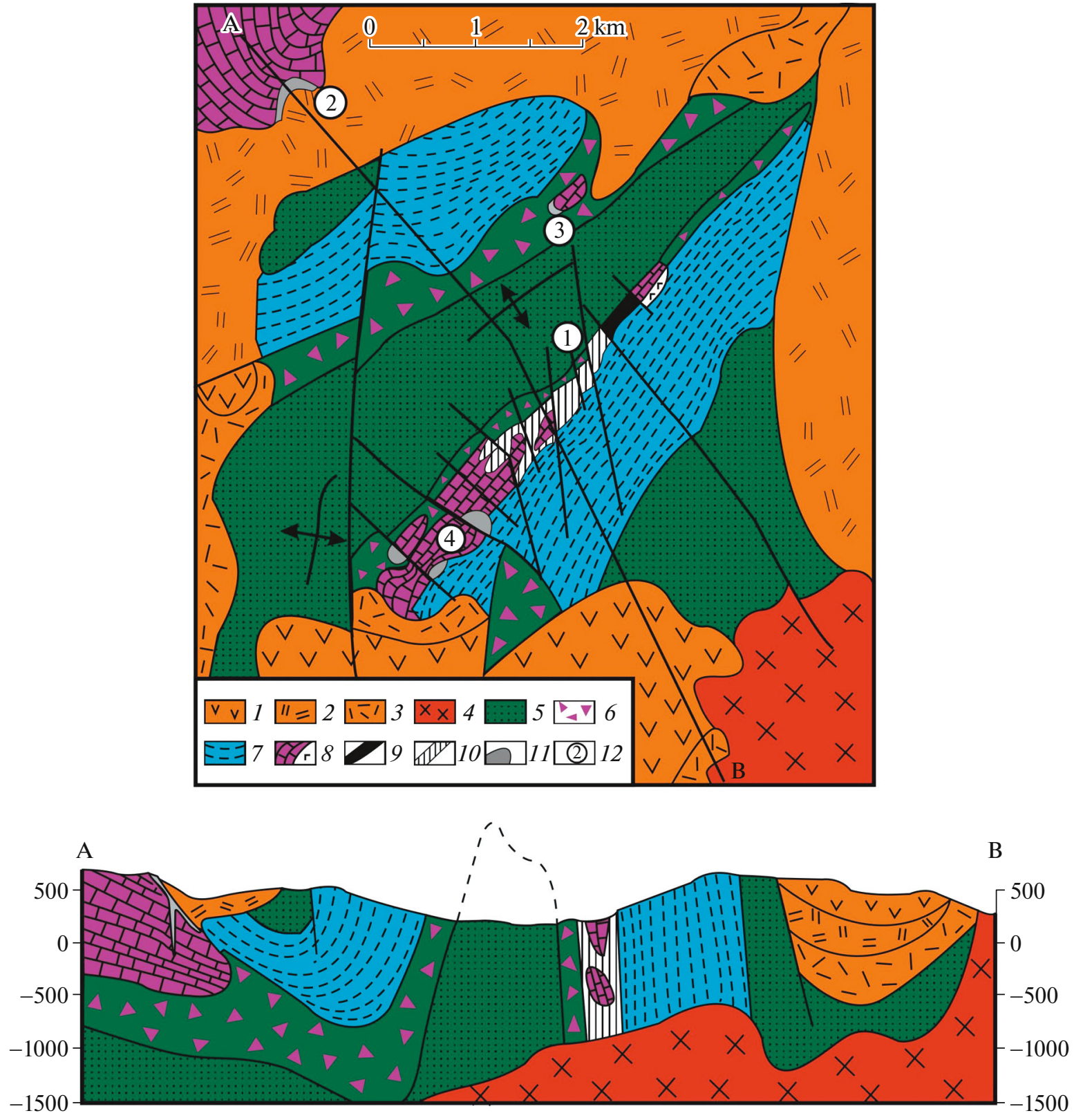

Fig. 1. Scheme of the geological structure of the central part of the Dalnegorsk ore region, according to [5] with changes and additions. 1-3, Late Cretaceous-Early Paleocene effusives and tuffs: 1, andesites; 2, rhyodacites and dacites; 3, rhyolites; 4, Late Paleocene intrusions of granodiorite-granite composition; 5-7, sedimentary rocks of the Taukha terrane (Late Jurassic-Early Cretaceous accretionary prism): 5 , matrix of the prism: sandstones and flyshoids, 6 , subduction mélange; 7-8, inclusions of fragments of the oceanic plate: 7, Triassic cherts and Jurassic siliceous-clayey rocks; 8 , Triassic limestones and basalts of atoll-guyots; 9 , relict zone of early danburite ores in grossular-wollastonite skarns of Campanian age; 10, zone of transformation and redeposition of early danburite ores-datolite ores in ilvaite-hedenbergite-andradite skarns of Paleocene age; 11, lead-zinc ores in the ilvaite-hedenbergite-andradite skarns of Paleocene age; 12, deposits: 1, Dalnegorskoe borosilicate; 2, Verkhnee lead-zinc;

3, Pervoe Sovetskoe lead-zinc; and, 4, Partizanskoe lead-zinc.

fills the interstitials and envelops, almost without corroding, garnet crystals (Fig. 3).

The studied inclusions in danburite skarnoids are compactly grouped in the crystal growth zones and vary widely in the phase ratio from essentially gaseous to liquid. The gas phase of the inclusions does not contain, according to Raman spectroscopy, juvenile gases, except for water vapor. The homogenization temperature of inclusions is close to $+410^{\circ} \mathrm{C}$. The temperature of the eutectic of gas-liquid inclusions is $-20^{\circ} \mathrm{C}$ and corresponds to a salt concentration of about $16.0 \mathrm{wt} \%$ eq. $\mathrm{NaCl}$. At the same time, the oxygen of danburite skarnoids is isotopically heavier, at $\delta^{18} \mathrm{O}$ values from +13.6 to $+14.3 \%$ [ [15]. Isotopically weighted oxygen 


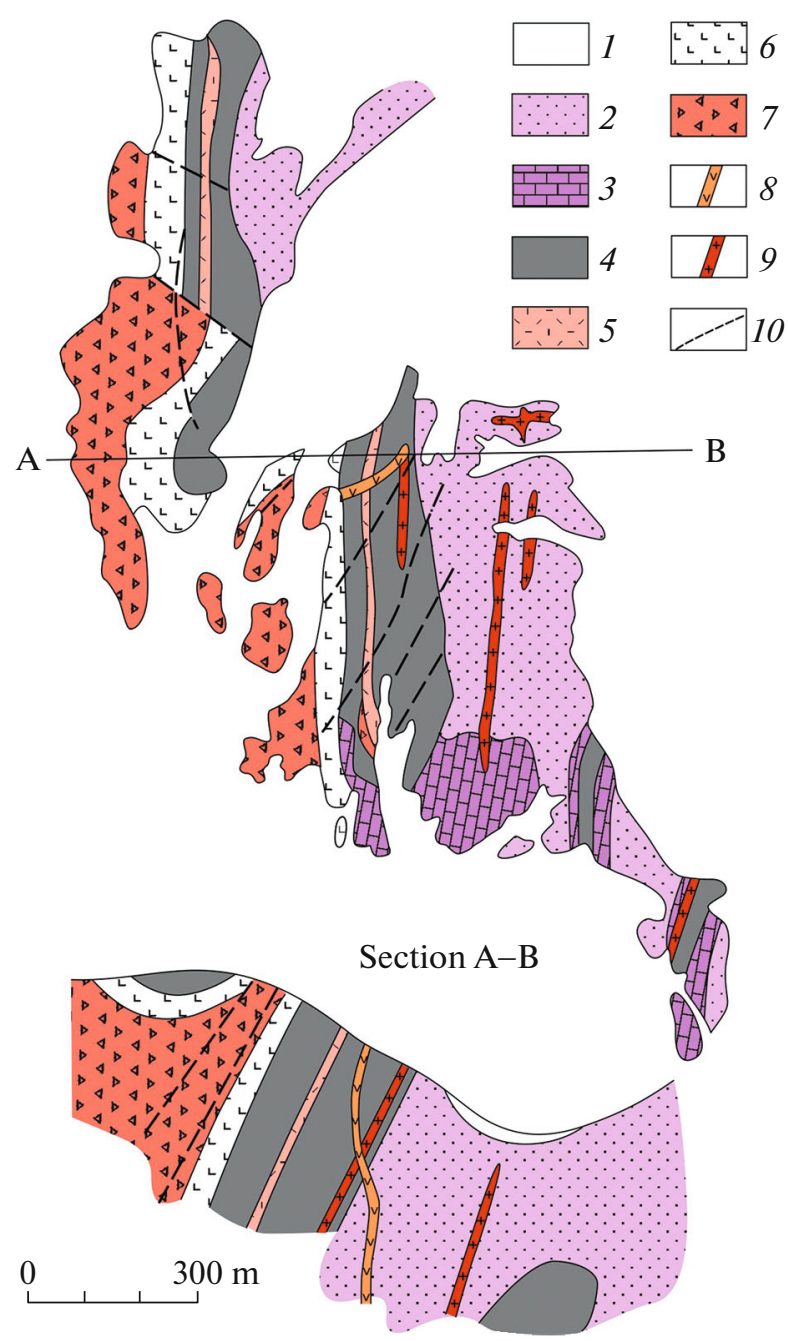

Fig. 2. Scheme of the Ak-Arkhar deposit geological structure, according to [14] with changes and additions. 1, Quaternary deposits; 2 , sandstones and flyschhoids of the Late Triassic (?) accretionary prism matrix; 3-6, rocks forming fragments of atoll-guyots (including 3-5, "caps" of guyots): 3, Lower-Upper Triassic limestones; 4, siliceouscarbonate rocks of the Upper Permian of lagoon origin, containing borosilicate ore bodies; 5, volcanomictic deposits of the Upper Permian; 6, basalts of the oceanic island volcanic base; 7, Lower Permian (?) sandy-shale deposits of unknown origin; 8 , Paleogene diabase dikes; 9, Early Cretaceous granitoids dikes; 10 , faults.

is also typical for skarnoid quartz. The quartz $\delta^{18} \mathrm{O}$ values vary in the range from +10.7 to $+16.0 \%$, with average values of $+13.3 \%$. Thus, the transformation of a fragment from lagoon deposits took place in the thermal field of the granitoid intrusion at an extremely low water/rock ratio and $\delta^{18} \mathrm{O}$ values of the metamorphogenic fluid, taking into account isotopic fractionation in the quartz $-\mathrm{H}_{2} \mathrm{O}$ system [16], at a level of $+10.0 \%$.

Observations performed at the Ak-Arkhar deposit to solve the problem of a highly concentrated source of

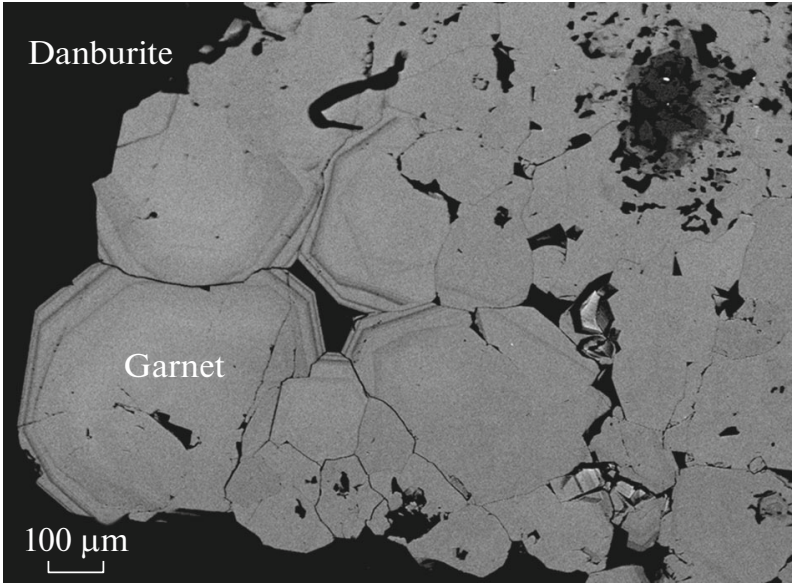

Fig. 3. Danburite-garnet aggregate in the ores of the AkArkhar deposit.

boron [10] are summed up as a conclusion about the formation of skarnoids with danburite in situ due to the selective replacement of saline clay-carbonate interlayers with borates in the layered strata formed in the pre-accretionary time in the lagoon at the top of the guyot.

\section{ACKNOWLEGMENTS}

The authors are grateful to N.A. Kharitonova for the samples and geological descriptions of the Ak-Arkhar deposit.

\section{REFERENCES}

1. A. I. Khanchuk, in Ore Fields of Continental Boundaries (Dal'nauka, Vladivostok, 2000), pp. 5-34 [in Russian].

2. A. I. Khanchuk, I. V. Kemkin, and N. N. Kruk, J. Asian Earth Sci. 120, 117-138 (2016).

3. A. I. Khanchuk, A. P. Nikitina, I. V. Panchenko, et al., Dokl. Akad. Nauk SSSR 307 (1), 186-189 (1989).

4. G. Peyrotty, S. Rigaud, I. Kemkin, and R. Martini, Global Planet. Change 184, 1-24 (2020). https://doi.org/10.1016/j.gloplacha.2019.103072

5. V. V. Ratkin, O. A. Eliseeva, M. S. Pandian, et al., Geol. Ore Deposits 60 (8), 672-684 (2018). https://doi.org/10.1134/S107570151808007X

6. V. V. Ratkin, L. N. Khetchikov, N. V. Gnidash, and V. E. Dmitriev, Tikhookean. Geol., No. 2, 97-108 (1993).

7. E. O. Dubinina, V. A. Baskina, and A. S. Avdeenko, Geol. Ore Deposits 53 (1), 58-74 (2011).

8. A. A. Alenicheva and V. G. Sakhno, Dokl. Earth Sci. 419 (2), 217-222 (2008).

9. N. A. Nosenko, V. V. Ratkin, P. I. Logvenchev, et al., Dokl. Akad. Nauk SSSR 312 (1), 178-182 (1990).

10. V. Yu. Prokof'ev, I. S. Peretyazhko, S. Z. Smirnov, et al., Boron and Boric Acids in Endogeneous Ore Form- 
ing Fluids (NPETs “Pas'va," Moscow, 2003) [in Russian].

11. O. A. Karas' and V. V. Ratkin, Dokl. Earth Sci. 455 (2), 411-414 (2014).

https://doi.org/10.1134/S1028334X14040060

12. L. D. Kurshakova, Physicochemical Formation Conditions of Skarn-Borosilicate Depositions (Nauka, Moscow, 1976) [in Russian].

13. D. Yogibekov, M. Sang, W. Xiao, et al., Geol. J. 55, 7837-7857 (2020).

https://doi.org/10.1002/gj.3906
14. A. E. Lisitsyn, Geological Foundations of Endogeneous Boron Depositions Search (Nedra, Moscow, 1974) [in Russian].

15. Yu. A. Borshchevskii, S. L. Borisova, N. I. Medvedovskaya, et al., in Proc. Int. All-Union Symp. on Stable Isotopes in Geochemistry (Moscow, 1982), Vol. 2, pp. 337-339.

16. R. N. Clayton, J. R. O’Neil, and T. K. Mayeda, J. Geophys. Res. 77, 3057-3067 (1972). https://doi.org/10.7868/S0024497X13060025

Translated by M.S. Nickolsky 